\title{
Occurrence of Aelurostrongylus abstrusus (Railliet, 1898) larvae (Nematoda: Metastrongylidae) infecting Achatina (Lissachatina) fulica Bowdich, 1822 (Mollusca: Gastropoda) in the Amazon region
}

\author{
Sanny Maria de ANDRADE- PORTO ${ }^{1}$, Kelly Cristina Pereira de SOUZA², Melissa Querido CÁRDENAS 3 ,

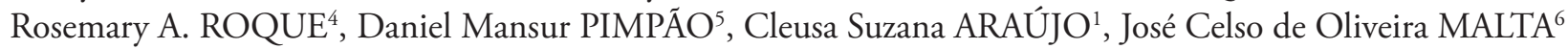

\section{ABSTRACT}

Achatina fulica or "giant African snail" is an exotic species, considered to be one of the world's hundred most invasive species, causing serious environmental damages. In the present study we report, for the first time, the occurrence of Aelurostrongylus abstrusus infecting $A$. fulica in the Amazon region. This nematode is described parasitizing mainly the pulmonary system of felines, which causes "aelurostrongilose", also known as feline cardio-pulmonary strongyloidosis. New morphometric data of third stage larvae are presented herein. The present study demonstrated that $40 \%$ of all the snails were infected by $A$. abstrusus. Achatina fulica specimens were collected from three different areas in Manaus namely: rural; east and west areas. The east area presents the highest prevalence of $80 \%$. The large number of $A$. fulica found in inhabited areas increases the chances of emergent zoonoses, which highlights the need of further studies so as to better control this disease.

KEYWORDS: Giant african snail; Parasitology; Nematode larvae; Helminth; Central Amazon.

\section{Ocorrência de Aelurostrongylus abstrusus (Railliet, 1898) (Nematoda: Metastrongylidae) infectando o Achatina (Lissachatina) fulica Bowdich, 1822 (Mollusca: Gastropoda) na região amazônica}

\begin{abstract}
RESUMO
Achatina fulica ou "caramujo africano" é uma espécie exótica, considerada uma das cem piores espécies invasoras do mundo, causando sérios danos ambientais. No presente estudo foi registrado, pela primeira vez, a ocorrência do Aelurostrongylus abstrusus infectando o $A$. fulica na região amazônica. Esse nematóide é descrito parasitando principalmente o sistema pulmonar de felinos, causando a "aelurostrongilose", também conhecida como estrongiloidose cardio-pulmonar felina. Novos dados morfométricos de larvas de terceiro estágio sáo apresentados. Dos 45 caramujos coletados, $40 \%$ estavam infectados por larvas de $A$. abstrusus. Especimens de Achatina fulica foram coletados em três áreas da cidade de Manaus: rural, leste e oeste. A zona leste apresentou a maior prevalência de $80 \%$. O grande número de $A$. fulica encontrado em áreas habitadas aumenta as chances de ocorrência de zoonoses emergentes e destaca a necessidade de mais estudos para o melhor controle da doença.
\end{abstract}

PALAVRAS-CHAVE: Caramujo gigante africano; Parasitologia; larvas de Nematoda; Helmintos; Amazônia central.

\footnotetext{
UNINILTONLINS, Universidade Nilton Lins. Laboratório de Zoologia Aplicada. Av. Professor Nilton Lins, 3259. Tel: (92) 36432022. Pq. das Laranjeiras, CEP 69058-040. Manaus, AM.sanny@inpa.gov.br; sanny.porto@yahoo.com.br

2 SEDEMA-Secretaria Municipal de Meio Ambiente, Prefeitura Municipal de Manaus, Avenida André Araújo, 1500. Aleixo. Tel: (92) 36480764 Manaus- AM CEP: 69.060-000. kelly. souza@pmm.am.gov.br

${ }^{3}$ FIOCRUZ. Instituto Oswaldo Cruz, Laboratório de Helmintos Parasitos de Peixes. Av. Brasil, 4365, Manguinhos, Rio de Janeiro, RJ. CEP: 21045-900. melissaq@ioc.fiocruz.br ${ }^{4}$ UNINILTONLINS, Universidade Nilton Lins. Laboratório de Entomologia Aplicada, sala 160. Av. Professor Nilton Lins, 3259. Tel: (92) 36432022. Pq. das Laranjeiras, CEP 69058040. Manaus, AM. rroque@niltonlins.br

${ }^{5}$ IBAMA. Instituto Brasileiro do Meio Ambiente e dos Recursos Naturais Renováveis, Escritório Regional de Gurupi. Av. Piaúi, 2090. Tel: (63) 33511318. Centro. CEP-77410-030 Gurupi, T0 - Brasil. danielpimpao@yahoo.com.br

${ }_{6}^{6}$ INPA. Instituto Nacional de Pesquisas da Amazônia. Coordenação de Biologia de Água Doce e Pesca Interior. Av. André Araújo, 2936, Aleixo, CEP 69060-001. Manaus - AM, Fone: (92)36433143. jcmalta@inpa.gov.br.
} 


\section{INTRODUCTION}

Aelurostrongylus abstrusus (Railliet 1898) is a nematode that causes "aelurostrongilose", also known as feline cardiopulmonary strongyloidosis. The adult form of this nematode inhabits the alveolar ducts, terminal bronchioles and small branches of the lung arteries (Scofield et al. 2005; Ferreira et al. 2007). It presents wide geographical distribution, and is the most frequently found $A$. fulica parasite (Thiengo et al. 2007; Thiengo et al. 2008).

The biological cycle of $A$. abstrusus is indirect; molluscs are the intermediate hosts. However, many parathenic hosts (such as reptiles, rodents, birds, amphibians, and little mammals that had eaten the intermediate host) may also participate in the biological cycle. The cat gets infected when it eats the intermediate or the parathenic hosts holding infective larvae $\left(\mathrm{L}_{3}\right)$. The free larvae can survive up to two weeks in the environment. If larvae are ingested by or penetrate the intermediate hosts, they become third stage infective larvae (Ferreira da Silva et al. 2005; Scofield et al. 2005).

The snail Achatina fulica (Bowdich 1822), native from East Africa, is one of $A$. abstrusus intermediate hosts (Thiengo et al. 2008; Oliveira et al. 2010; Pereira 2010). The introduction of this species into Brazil came about through it being bred for non-successful commercial purposes (Thiengo et al. 2008). Nowadays it is present in 24 of all the 26 Brazilian states as well as the federal capital, Brasília, including the Amazon region and natural reserves (Thiengo et al. 2008; Thiengo and Fernandez 2010).

The veterinary importance of $A$. fulica, participating in the biological cycles in the wild and domestic fauna in Brazil, has been reported in several works undertaken by various authors (Bessa et al. 2000; Thiengo et al. 2007; Thiengo et al. 2008; Oliveira et al. 2010; Pereira 2010). Achatina fulica is frequently infected with larvae of $A$. abstrusus, Rhabditis sp., Strongyluris sp. and Angiostrongylus vasorum (Baillet 1866) (Bessa et al. 2000).

Besides being the intermediate host of the afore mentioned nematodes, $A$. fulica may also act in the transmission of nematodes important to public health as a whole, Angiostrongylus cantonensis (Chen 1935) and Angiostrongylus costaricensis (Morera e Céspedes 1971) (Maldonado et al. 2010; Thiengo et al. 2010).

The presence of this mollusc in Manaus is alarming. According to the data of the Department of Environment of the State of Amazon- SEDEMA/AM, the geographical distribution and prevalence of the $A$. fulica has been increasing since 2004 . Nearly $5.020 \mathrm{~kg}$ of this snail were collected from March to July 2004. The east and central-west areas held 83\% of all the collected samples (SEDEMA 2005).
Since $A$. fulica is an intermediate host of several helminthiaisis with veterinary and zoonotic importance (Maldonado et al. 2010; Oliveira et al. 2010; Pereira, 2010; Thiengo et al. 2007; Thiengo et al. 2008; Thiengo et al. 2010). Thus, the aim of the present study is to verify the occurrence of nematode larvae in the A. fulica collected from Manaus as well as their medical-veterinary importance.

\section{MATERIALS AND METHODS}

Snails were collected manually, still alive, during the rainy season in Manaus (January to March, 2006). Specimens were collected from three different areas: rural (2० $44^{\prime} 32^{\prime \prime S}$ and $59^{\circ} 51^{\prime} 12^{\prime \prime} \mathrm{W}-\mathrm{AM} 010$ ); west (3०04' $8^{\prime \prime} \mathrm{S}$ and $60^{\circ} 03^{\prime}$ 04”W Campos Elíseos neighborhood); east (-03 $04^{\prime} 20^{\prime \prime}$ and $-59^{\circ} 56^{\prime} 48^{\prime \prime}$ - Jorge Teixeira neighborhood ). The landscape characteristics of where the collections were carried out are described in Table 1.

Fifteen $A$. fulica were collected from each area. Achatina fulica that were about $4.4( \pm 1.54) \mathrm{cm}$ long were placed in plastic tanks, wrapped with moistened paper towels and transported to the laboratory of the National Institute of Amazonian Research- INPA where they were separated according to their size. The snails were kept in glass terrariums with dimensions of $50 \times 30 \times 20 \mathrm{~cm}$ covered with mesh so as to prevent their escape and allow for the entrance of oxygen. The snails were fed "ad libitum" with fresh lettuce leaves until the moment of the necropsy.

During the all snail manipulation process we used individual protection equipments (IPEs) so as to prevent laboratorial contamination. Pieces of cellophane paper were placed into the terrariums for $24 \mathrm{~h}$ periods. Following these periods the cellophane papers were observed in the stereoscopic microscope in order to view the molluscs releasing the larvae (Vasconcellos and Pile 2001).

Table 1- Characteristics of the land where Achatina fulica were collected.
$\begin{gathered}\text { Collection areas } \\ \text { Rural }\end{gathered}$
$\begin{array}{r}\text { Farm house yards with cassava and papaya planta- } \\ \text { tions. Peridomestic area of native vegetation. } \\ \text { No rubbish. }\end{array}$
West
$\begin{gathered}\text { Green area of the set, with fragments of secondary } \\ \text { vegetation, moist soil with rocks. Neighborhood with } \\ \text { good sanitary conditions. }\end{gathered}$
Vacant lots with trash, accumulated debris, stones
and debris of construction material. Backyards of
residential areas with fruit trees, presence of too
much garbage and moist soil. Neighborhood with
poor sanitary conditions


Achatina fulica specimens were analyzed right after their death. During necropsy procedures, the mucus released by the snails was analysed through the smear and observed in optical microscope. The snails were killed by submerging them in (500 mL flasks) with water and no air. After 12 hours each snail was removed from the container and had its shell carefully broken and was then dissected. The snails had their cephalopodal mass eviscerated and individually placed on Petri plates with distilled water.

Nematodes were fixed with hot AFA (2\% glacid acetic acid, $3 \%$ formaldehyde, and $95 \%$ of $70^{\circ}$ ethanol). For light microscopy study, nematodes were clarified in 50\% phenol. Measurements are shown in micrometers $(\mu \mathrm{m})$ unless otherwise indicated, and are quoted as the ranges with means in parenthesis.

Identification of the nematodes is based on morphological and morphometric parameters following Ash (1970). Specimens of $A$. abstrusus larvae were deposited in the Helminthological Collection of the Oswaldo Cruz Institute no 35720 CHIOC. (wet material).

The Bioestat program version 5.0 was used to make a descriptive analysis of the data, as well as a correlation analysis in order to verify whether there was an association between these variables: size of the snail, number of parasites and area where the molluscs were collected. A simple and multiple regression analysis was done to verify the correlation between the variables. The Kruskal Wallis and Mann Whitney nonparametric tests were used to compare the size of the snails and the number of parasites found in the mollusc, respectively. They compared the averages using the test of Dunn in a 5\% probability (Ayres et al. 2007).

\section{RESULTS AND DISCUSSION}

From 45 collected samples of $A$. fulica, 18 (40\%) were infected with third stage larvae of $A$. abstrusus (Figure 1). Morphometric analysis of third stage larvae obtained by light microscopy is shown in Table 2. Parasitic indexes and infection sites of $A$. abstrusus the three collecting areas are described in Table 3.

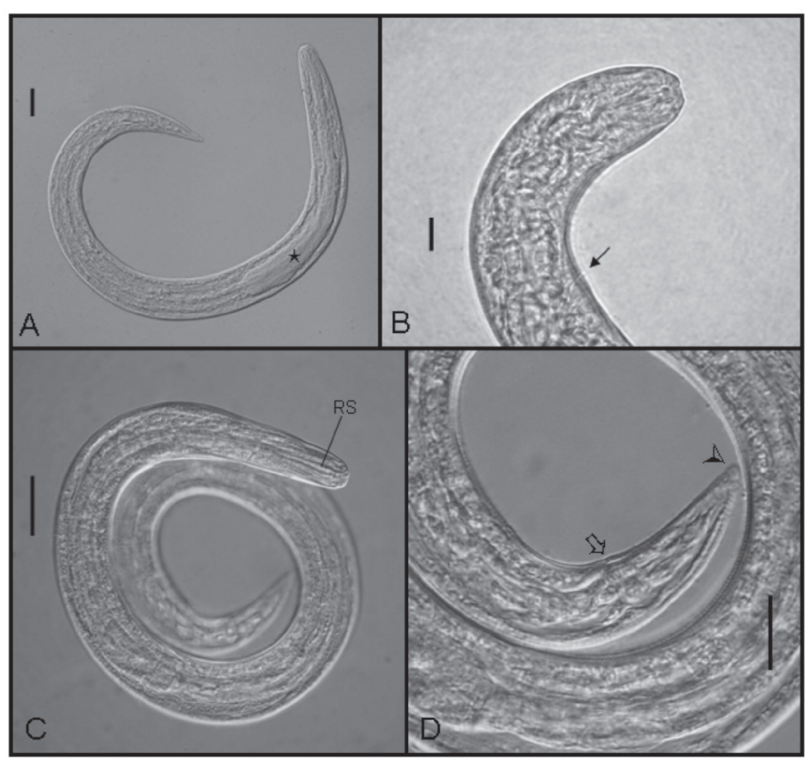

Figure 1 - Light microscopy of Aelurostrongylus abstrusus infective larvae recovered from Achatina fulica. A. General view observed by differential interference contrast (DIC) showing the esophagus (star). Bar $20 \mu \mathrm{m}$. B. Anterior region of infective larvae showing the excretory pore (arrow). Bar $10 \mu \mathrm{m}$. C. General view observed by differential interference contrast (DIC) of infective larvae showing rod-like structure (RS). Bar $20 \mu \mathrm{m}$. D. Posterior region showing the anus (thick arrow) and the knob like tip tail (arrowhead) observed by differential interference contrast (DIC). Bar $10 \mu \mathrm{m}$.

Table 2 - Measurements (in $\mu \mathrm{m}$ ) of Aelurostrongylus abstrusus third stage larvae. Means are in parentheses.

\begin{tabular}{lc}
\hline Measurements & $\begin{array}{c}\text { Aelurostrongylus } \\
\text { abstrusus larvae }\end{array}$ \\
\hline Specimens measured & 7 \\
Length & $330-416(387)$ \\
Nervous ring & $40-72(54)$ \\
Excretory pore & $48-76(58)$ \\
Esophagus & $130-174(156)$ \\
Anus* & $20-32(25)$ \\
\hline
\end{tabular}

* Distance from the posterior end.

Table 3 - Parasitological indexes and site of infection of Achatina fulica in Aelurostrongylus abstrusus collected in three areas in the city of Manaus.

\begin{tabular}{|c|c|c|c|c|c|c|}
\hline \multirow{2}{*}{ Collection areas } & \multirow{2}{*}{$\begin{array}{l}\text { Number of } \\
\text { Aelurostrongyls } \\
\text { abstrusus }\end{array}$} & \multicolumn{4}{|c|}{ Parasites indexes } & \multirow{2}{*}{ Site of infection } \\
\hline & & Prevalence (\%) & $\begin{array}{l}\text { Intensity } \\
\text { variation }\end{array}$ & $\begin{array}{c}\text { Mean } \\
\text { Intensity }\end{array}$ & $\begin{array}{c}\text { Mean } \\
\text { Abundance }\end{array}$ & \\
\hline Rural & $18 b$ & $33.3 b$ & $1-6$ & 3.6 & $1.2 \mathrm{~b}$ & Lung Mucus \\
\hline East & $716 a$ & $80 \mathrm{a}$ & $1-199$ & 59.66 & $47.7 \mathrm{a}$ & Mantle Mucus \\
\hline West & 0 & 0 & 0 & 0 & 0 & - \\
\hline
\end{tabular}

The mean presented in the same column and followed by different letters indicate significant statistic difference (Dunn e Mann Whitney test, $p<0,05)$. 
Cysts with larvae of $A$. abstrusus were visualized in the pallial cavity of three molluscs. They were also found to present the highest rates of infection in the sample from the east area, with a prevalence of $80 \%$. The parasite prevalence rates of the rural and west areas were $1 \%$ and $0 \%$, respectively. We verified a significant difference between the number of $A$. abstrusus that was found in the $A$. fulica from the east area when compared to those from the rural area $(\mathrm{p}=0.0015)$ (Table 3).

We found a significant and negative correlation $(\mathrm{p}=$ $0.0088 / \mathrm{rs}=-0.38$ ) between the three surveyed areas (rural, east and west) and the size of the A. fulica collected. The Kruskal Wallis test indicated a significant difference between the sizes of the snails from the rural area in comparison to those from the west area $(\mathrm{p}=0.004)$. The simple linear regression showed the dependence relation between these two variables area and size of the snails - $\left(\mathrm{R}^{2}=0.19 ; \mathrm{p}=0.0029\right)$ (Figure 2).

A significant and positive correlation $(\mathrm{rs}=0.62 \mathrm{p}=$ 0.0003 ) between the collection areas and the number of $A$. abstrusus was verified only when comparing two areas (rural and east). The simple linear regression analysis also showed the variables dependence relation of the variables $\left(R^{2}=0.23\right.$; $\mathrm{p}=0.008)($ Table 3$)$.

The recent introduction of $A$. fulica in Brazil must be regarded with caution by health authorities. The human activities in addition to its high reproductive capacity and lack of natural pathogens have led to rapid dispersal even among distant regions including the Amazon (Thiengo et al. 2008).

Achatina fulica was abundant in the three collecting areas in the city of Manaus. The mean size of the collected snails was $4.4( \pm 1.54 \mathrm{~cm})$. Despite literature pointing out adults to easily reach from 10 up to $12 \mathrm{~cm}$ shell length, the largest specimens collected by Pereira (2010) in Rio de Janeiro were at most 8 to $9 \mathrm{~cm}$ long (Pereira 2010). This indicates the likelihood of the $A$. fulica collected in the present study being a young population with little colonization time in the area.

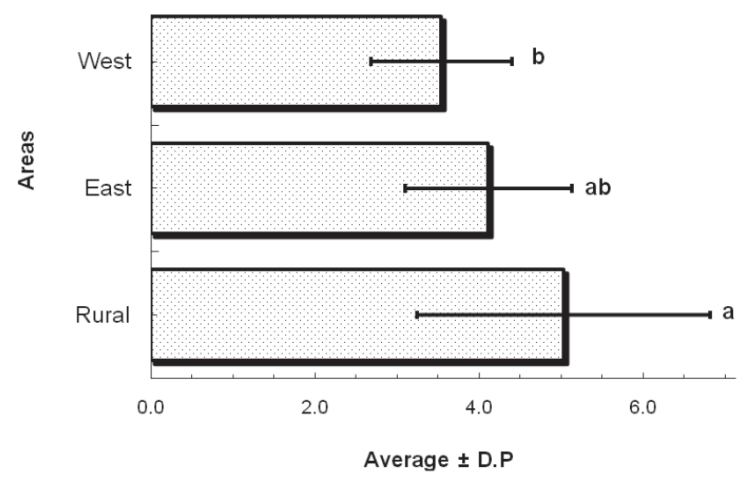

Figure 2 - Average sizes of the Achatina fulica (Mollusca: Achatinidae) snail collected from three areas of Manaus/AM.
The present study reports, for the first time, the presence of A. abstrusus third stage larvae found in A. fulica collected in the rural area and east area of Manaus. Aelurostrongylus abstrusus is the most frequent metastrongilídeo found in A. fulica specimens at the National Medical Malacology Reference Laboratory (LRNM, IOC, FIOCRUZ) (Thiengo et al. 2008).

Spite of this mollusks' wide distribution in the Amazon, other studies on helmintofauna are yet to report this species' occurrence. A. abstrusus larvae were found in A. fulica specimens from Brazil's Northeast Midwest and Southeast regions, excepting the northern and southern regions (Zanol et al. 2010).

The east area, namely, the Jorge Teixeira neighborhood, showing poor housing and basic sanitary conditions, was the one presenting the largest number of infected $A$. fulica. According to reports from people living near to where the $A$. abstrusus were collected, one may usually find a large number of mice and cats. These animals are known to take part in this parasite's natural life cycle (Ferreira da Silva et al. 2005; Scofield et al. 2005), moving easily to other environments, and infecting mollusks from other localities (Ferreira et al. 2007). The infected cats eliminate the first stage larvae in feces, disseminating the parasite. Then, the larvae become available in the environment and are ingested or penetrate $A$. fulica, in which they develop to third stage larvae (Ferreira et al. 2007).

The rural area, where the snails ( $A$. fulica) were present in farm house yards with cassava and papaya plantations, individuals were dispersed on fruit tree branches and soil close to the roots were collected. Unlike the east area there was no rubbish because the people living in this area have the habit of burning it. No infected $A$. fulica was found in the west area, there were also no rubbish or small animals that could be parasitic and definitive hosts.

Achatina fulica proliferation and the occurrence of intermediate and definitive hosts occurs in the most efficient way in environments with resting sites (construction debris, hedges) and lots of food (garbage, ornamental plants and fruit trees) (Fischer and Colley 2004). Vegetation diversity and abundance are factors that provide shelter and abundant food to mollusks and other animals (Pereira 2010). These factors may have been limiting to account for the lack of infected snails in the west area.

In the seven Brazilian states, in which 3806 A. fulica were examined, the prevalence was $5.67 \%$ and the intensity ranged from 1-81 (Thiengo et al. 2008). In the Barra do Pirai (RJ), 55 snails were examined and the prevalence was 27\% (Pereira 2010). In the Goiás state 149 A. fulica were examined and the prevalence was $26.8 \%$ (Oliveira et al. 2010). In this study the prevalence of $A$. abstrusus was $40 \%$ and intensity variation 1-199 A. abstrusus per A. fulica, 
these results can be considered high when compared to other studies.

Cysts with nematodes larvae in the pallial cavity of the $A$. fulica were observed Thiengo (1995). Cysts of $A$. abstrusus also were observed in A. fulica and the native snail Megalobulimus sp. Larvae of the second and third stage were described in $A$. fulica from seven Brazilian State: Rio De Janeiro; Sao Paulo; Espírito Santo; Goiás; Mato Grosso; Sergipe; and Minas Gerais (Thiengo et al. 2008).

In the present study, only larvae of the second stage were found, and its measurements are lower than that found by Thiengo et al. (2008). These differences could be due to the fact that the size attained by larvae may be influenced by several factors, such as the number of larvae developing in the intermediate host, the age of larvae in the mollusc and the fixation and clearing methods (López et al. 2005).

Besides being an intermediate host of helminths (Nematode and Trematode: Digenean) of veterinary importance to domestic animals. Achatina fulica can also become intermediate hosts of parasites of wild animals becoming a risk for wild fauna biodiversity (Thiengo et al. 2008). Then, studies of $A$. fulica are necessary in order to determine the health risks for human population and veterinary implications. Aelurostrongylus abstrusus is being reported in the Amazon region for the first time, broadening the distribution of this parasite in Brazil.

\section{ACKNOWLEDGMENTS}

We are thankful to the Department of Environment of the State of Amazonas (SEDEMA-AM) for their assistance in the collecting of the African snails Achatina fulica.

\section{LITERATURE CITED}

Ash, R.L. 1970. Diagnostic morphology of the third-stage larvae of Angiostrongylus vasorum cantonensis, Aelurostrongylus abstrusus and Anafilaroides rostratus (Nematoda: Metastrongyloidea). The Journal of Parasitology, 56 (2): 249-253.

Ayres, M.; Ayres Jr., M.; Ayres, D.L.; Santos, A.S. 2007. BioEstat5.0: statistical applications in the areas of biological and medical sciences. Belém: Sociedade Civil Mamirauá/Brasília: $\mathrm{CNPq} /$ Conservation International.

Bessa, E.C.A.; Lima, W.S.; Daemon, E.; Cury, M.C.; Araújo, J.L.B. 2000. Biological development of Angiostrongylus vasorum (Baillet) Kamensky (Nematoda, Metastrongylidae) in Subulina octona Bruguiere (Mollusca, Subulinidae) in laboratory conditions. Revista Brasileira de Zoologia, 17(1): 29-41. (in Portuguese, with abstract in English).

Ferreira, A.M.R.; Souza-Dantas, L.M.; Labarthe, N. 2007. Report of a case of Aelurostrongylus abstrusus (Railliet, 1898) in a domestic cat in Rio de Janeiro. Brazilian Journal of Veterinary Research and Animal Science, 44: 24-26.
Ferreira da Silva, J.M.; Pereira da Fonseca, I.M.; Madeira de Carvalho, L.M.; Meireles, J.A.F.S.; Fazendeiro, I. 2005. Aelurostrongylus abstrusus pneumonia in a cat - need for a precocious diagnosis. Revista Portuguesa de Ciências Veterinária, 100: 103-106.

Fisher, M.L.; Colley, E. 2004. Diagnosis of occurrence of the giant African snail Achatina fulica Bowdich, 1822 na APA de Graraqueçaba, Paraná, Brasil. Estudos de Biologia, 26 (54): 43-50.

López, C.; Panadero, R.; Paz, A.; Sanchez-Andrade, R.; Díaz, P.; Díez-Baños, P.; Morrondo, P. 2005. Larval development of Aelurostrongylus abstrusus (Nematoda, Angiostrongylidae) in experimentally infected Cernuella (Cernuella) virgata (Mollusca, Helicidae). Parasitology Research, 95: 13-16.

Maldonado, A.; Simôes, R.O.; Oliveira, A.P.M.; Motta, E.M.; Fernandez, M.A.; Pereira, Z. M.; Monteiro, S.S.; Torres, E.J.L.; Thiengo, S.C. 2010. First report of Angiostrongylus cantonensis (Nematoda: Metastrongylidae) in Achatina fulica (Mollusca: Gastropoda) from Southeast and South Brazil. Memórias do Instituto Oswaldo Cruz, 105(7): 938-941.

Oliveira, A.P.M.; Torre, E.J.L.; Maldonado Jr., A.; Araújo, J.L.B.; Fernandez, M.A.; Thiengo, S.C. 2010. Achatina fulica as an intermediate host of nematoda of medical-veterinary interest in Goiás, Brazil. Revista de Patologia Tropical, 39(3): 199-210. (in Portuguese, with abstract in English).

Pereira, Z.M. 2010. Study of the perceptions of students from public network and helminthofauna associated with the African snail Achatina fulica Bowdich, 1822 (Mollusca, Gastropoda) in Barra do Pirai (RJ): support for an educational intervention. Dissertação de Mestrado. Instituto Oswaldo Cruz, Rio de Janeiro. 101pp. (in Portuguese).

SEDEMA. 2005. Report of the Campaign for Control of African Snail. Secretaria Municipal de Desenvolvimento e Meio Ambiente do Estado do Amazonas. 10pp. (in Portuguese).

Scofield, A.; Madureira, R.C.; Oliveira, C.J.F.; Guedes Jr., D.S.; Soares, C.O.; Fonseca, A.H. 2005. Postmortem diagnosis of Aelurostrongylus abstrusus and morphometric characterization of eggs and morulae by histology and tissue imprint. Ciência Rural, 35: 952-955.

Thiengo, S.C. 1995. Presence of strongyluris-like larvae (Nematode) in some terrestrial molluscs in Brazil. Memórias do Instituto Oswaldo Cruz, 90: 619-620.

Thiengo, S.C.; Faraco, F.A.; Salgado, N.C.; Cowie, R.; Fernandez, M.A. 2007. Rapid spread of an invasive snail in South America: the giant African snail, Achatina fulica, in Brasil. Biology Invasion, 9: 693-702.

Thiengo, S.C.; Thiengo, M.A.; Torres, E.J.L.; Coelho, P. M.; Lanfredi, R.M. 2008. First record of a nematode Metastrongyloidea (Aelurostrongylus abstrusus larvae) in Achatina (Lissachatina) fulica (Mollusca, Achatinidae) in Brazil. Journal of Invertebrate Pathology, 98: 34-39.

Thiengo S.C.; Maldonado, A.; Mota, E.M.; Torres, E.J.; Caldeira, R.; Carvalho, O.S.; Oliveira, A.P.; Simôes, R.O.; Fernandez, M.A.; Lanfredi, R.M. 2010. The giant African snail Achatina fulica as natural intermediate host of Angiostrongylus cantonensis in Pernambuco, northeast Brazil. Acta Tropica, 115(3): 194-9. 
Thiengo, S.C.; Fernandez, M.A. 2010. Achatina fulica: a public health problem? In: Fischer, M.L.; Costa, L.C.M. (Eds.) The giant African snail Achatina fulica in Brazil. Champagnat Editora - PUCPR, Curitiba, p. 189-202. (in Portuguese).

Vasconcellos, M.C.; Pile, E. 2001. Occurrence of Achatina fulica in the vale do Paraíba, Estado do Rio de Janeiro, Brazil. Revista de Saúde Pública, 35: 582-584. (in Portuguese, with abstract in English).
Zanol, J.; Fernandez, M.A; Oliveira, A.P.M.; Russo, C.A.M.; Thiengo, S.C. 2010. The exotic invasive snail Achatina fulica (Stylommatophora, Mollusca) in the State of Rio de Janeiro (Brazil): current status. Biota Neotropica,10 (3): 447-451. (in Portuguese, with abstract in English).

Recebido em 17/12/2010

Aceito em 06/06/2011 